\title{
KESANTUNAN TINDAK TUTUR DALAM INTERAKSI AKADEMIK
}

\author{
Muhammad Saleh dan Baharman \\ Fakultas Bahasa dan Sastra, Univeritas Negeri Makassar \\ Jalan Daeng Tata Raya, Kampus Parangtambung UNM, Makassar \\ Email:muhammadsaleh.unm@gmail.com
}

\begin{abstract}
A Form of The Students' Language Politeness in Academic Interaction. This study aimed to describe and explain the propriety of speech act in academic interactions. This study includes the type of qualitative research using ethnography of communication design theory, speech act theory, and the theory of linguistic politeness. The research data consists of data conversations and field notes. Data collected through recording techniques, observation, interviews, and transcriptions. Data analysis was carried out through four main procedures, namely: data collection, data reduction, data presentation, and conclusions/verification. Based on data analysis, politeness of speech act are classified into four, namely: (1) civility in act assertively, (2) acts of civility in the directive, (3) civility in commissive act, and (4) civility in expressive acts.
\end{abstract}

\begin{abstract}
Abstrak: Kesantunan Tindak Tutur dalam Interaksi Akademik. Penelitian ini bertujuan untuk mendeskripsikan kesantunan tindak tutur dalam interaksi akademik. Penelitian ini termasuk jenis penelitian kualitatif dengan menggunakan ancangan teori etnografi komunikasi, teori tindak tutur, dan teori kesantunan berbahasa. Data penelitian terdiri atas data tuturan dan catatan lapangan. Pengumpulan data dilakukan melalui teknik perekaman, observasi, wawancara, dan transkripsi. Analisis data dilakukan melalui empat prosedur utama, yakni: pengumpulan data, reduksi data, penyajian data, dan penyimpulan/verifikasi. Berdasarkan analisis data, kesantunan tindak tutur diklasifikasi menjadi empat, yakni: (1) kesantunan dalam tindak asertif; (2) kesantunan dalam tindak direktif; (3) kesantunan dalam tindak komisif; dan (4) kesantunan dalam tindak ekspresif.
\end{abstract}

Kata kunci: interaksi akademik, kesantunan, dan tindak tutur.

Kesantunan berbahasa dalam tindak tutur bahasa Indonesia merupakan salah satu parameter peradaban bahasa. Dalam skala yang lebih global, kesantunan berbahasa merupakan salah satu pilar terwujudnya pendidikan damai dalam rangka membentuk manusia yang berperadaban dan bermartabat tinggi dalam berbagai bentuk komunitas. Bahkan, kesantunan berbahasa merupakan salah satu dimensi pendidikan yang perlu mendapat perhatian dalam rangka terwujudnya pengembangan pendidikan yang sustainable.

Variasi penggunaan wujud kesantunan berbahasa menunjukkan bahwa ekspresi kesantunan berbahasa didasarkan pada tujuan dan fungsi yang beragam. Fungsi tersebut merepresentasikan adanya kekuatan yang ditimbulkan oleh penggunaan suatu ujaran, seperti perintah, pujian, ejekan, keluhan, janji, dan sebagainya
(Mey, 1996), yang selanjutnya diidentifikasi sebagai tindak ilokusi. Secara fungsional, Searle membagi tindak ilokusi menjadi lima jenis. Pertama, tindak asertif berfungsi untuk menyatakan sesuatu agar dapat dinilai benar atau tidaknya, misalnya menyatakan, mengusulkan, membual, mengeluh, mengemu-kakan pendapat, melaporkan. Kedua, tindak direktif berfungsi untuk menyatakan permintaan untuk melakukan atau berhenti melakukan sesuatu, misalnya memesan, memerintah, memohon, menuntut, memberi nasihat. Ketiga, tindak komisif berfungsi untuk menyatakan sesuatu yang menunjukkan bahwa penutur sedikit banyak terikat pada suatu tindakan di masa depan, misalnya menjanjikan, menawarkan. Keempat tindak ekspresif berfungsi untuk menyatakan sesuatu yang mencerminkan sikap psikologis penutur terhadap keadaan, 
misalnya: mengucapkan terima kasih, mengucapkan selamat, memberi maaf, mengecam, memuji, mengucapkan belasungkawa. Kelima, tindak deklarasi mengakibatkan adanya kesesuaian antara isi proposisi dengan realitas, misalnya, mengundurkan diri, membaptis, memecat, memberi nama, menjatuhkan hukuman, dan sebagainya (Leech, 1993).

Tuntutan untuk menggunakan pilihan bahasa sesuai dengan struktur dan fungsi sosial budaya menjadikan kesantunan berbahasa dalam interaksi mahasiswa di lingkungan kampus menjadi rumit. Oleh karena itu, ketika berkomunikasi, mahasiswa perlu mempertimbangkan pilihan bahasa serta strategi yang tepat dalam menyampaikan suatu pesan berdasarkan konteks situasional dan sosialkultural yang berlaku, khususnya dalam lingkungan kampus. Hal ini berarti bahwa mahasiswa perlu memunyai pemahaman dan kemampuan menggunakan ragam wujud kesantunan berbahasa berdasarkan fungsinya melalui strategi tertentu sesuai dengan konteks sosial budaya yang berlaku dalam interaksi akademik di lingkungan kampus. Oleh karena itu, mahasiswa perlu memiliki pengetahuan komunikasi (kompetensi komunikatif) secara tepat yang mencakup: (1) pengetahuan linguistik; (2) keterampilan interaksi; dan (3) pengetahuan kebudayaan (Ibrahim, 1994).

Kesantunan berbahasa sebagaimana yang telah diuraikan menarik untuk dikaji di kalangan mahasiswa, khususnya mahasiswa. Oleh karena itu, pengkajian terhadap kesantunan berbahasa di kalangan mahasiswa menjadi sangat berarti bagi pembinaan, dan pengembang-an nilai-nilai budaya, khususnya budaya berba-hasa. Dengan demikian, penelitian ini memiliki implikasi edukatif yang sangat berarti dalam rangka menata pendidikan yang bermartabat.

Jika kesantunan berbahasa sebagaimana yang telah diuraikan di atas digunakan secara tepat akan memperlancar interaksi dalam masyarakat pada umumnya dan dalam interaksi mahasiswa kepada dosen atau kepada sesama mahasiswa pada khususnya. Sebaliknya, jika kesantunan berbahasa tersebut diabaikan, dapat menimbulkan terjadinya gangguan komunikasi bahkan kesalahpahaman dalam kegiatan interaksi, baik dalam lingkungan masyarakat pada umumnya maupun interaksi mahasiswa kepada dosen atau sesama mahasiswa.

Penelitian kesantunan tetap perlu dilakukan untuk menambah wawasan penelitian kesan- tunan berbahasa yang sudah ada. Penelitian ini akan melengkapi hasil-hasil penelitian terdahulu, baik terhadap aspek honorifik, tindak tutur, maupun aspek kesantunan berbahasa.

\section{METODE}

Penelitian ini menggunakan pendekatan kualitatif. Analisis data dilakukan melalui model interaktif dan dilakukan sejak penggumpulan data. Penafsiran data dilakukan dengan menggunakan alur berpikir struktural-fungsional. Dengan alur ini, setiap data dilihat dari struktur dan bergerak kepada fungsi-fungsinya dalam proses komunikasi.

Penelitian ini memunyai dua jenis data, yakni data tuturan dan data catatan lapangan. Berpijak pada fokus penelitian, data tuturan berisi strategi kesantunan berbahasa. Data catatan lapangan berisi tentang konteks kesantunan berbahasa. Data penelitian dikumpulkan dengan menggunakan tiga teknik, yakni perekaman, observasi, dan wawancara. Secara makro, data penelitian yang berupa kesantunan tindak tutur dianalisis dengan menggunakan prosedur analisis data kualitatif model etnografi komunikasi interaktif.

\section{HASIL PENELITIAN}

Berdasarkan fokus penelitian, kesantunan tindak tutur dalam interaksi akademik direpresentasikan secara beragam melalui berbagai tindak ilokusi. Secara garis besar, kesantunan tindak tutur diklasifikasi menjadi empat, yakni: (1) kesantunan dalam tindak asertif; (2) kesantunan dalam tindak direktif; (3) kesantunan dalam tindak komisif; dan (4) kesantunan dalam tindak ekspresif.

\section{Kesantunan dalam Tindak Asertif}

Tindak asertif sangat potensial digunakan dalam interaksi akademik. Hal ini terkait dengan karakteristik interaksi akademik sebagai domain pendidikan dan pembelajaran yang senantiasa mengedepankan nilai kebenaran dari setiap informasi yang disampaikan. Informasi yang disampaikan dalam interaksi akademik cukup beragam sehingga fungsi asertif yang diembannya pun beragam. Keragaman fungsi asertif demikian juga berimplikasi pada keragaman fungsi 
kesantunan yang direpresentasikannya. Berdasarkan hasil penelitian, tindak asertif yang digunakan mahasiswa dalam interaksi akademik mengemban beragam sebagaimana diuraikan dalam paparan berikut.

\section{Mengemukakan Pendapat}

Tindak asertif mengemukakan pendapat merupakan jenis tindak asertif yang lazim digunakan dalam interaksi mahasiswa dengan dosen dalam kegiatan akademik. Tindak asertif mahasiswa yang berorientasi pada mengemukakan pendapat lazim terjadi sebagai respon mahasiswa ketika dosen mengajukan pertanyaan kepada mahasiswa. Hal ini dapat ditemukan dalam interaksi akademik, khususnya dalam seminar hasil penelitian maupun dalam ujian skripsi.

\section{Mempertahankan Pendapat}

Salah satu fungsi kesantunan berbahasa dalam tindak asertif adalah mempertahankan pendapat. Jika dikaitkan dengan fungsi sosialnya, tindak mempertahankan pendapat cenderung bersifat kompetitif, yakni daya ilokusinya bersaing dengan tujuan sosial. Hal ini berarti bahwa tindak mempertahankan pendapat ini berpotensi menimbulkan konflik dan konfrontasi antarpartisipan. Oleh karena itu, kesantunan dalam tindak mempertahankan pendapat ini sangat diperlukan untuk mempermudah interaksi dan memperkecil potensi terjadinya konflik dan konfrontasi antarpartisipan.

Sejalan dengan tindak mengemukakan pendapat, tindak asertif yang berfungsi mempertahankan pendapat juga lazim terjadi dalam interaksi mahasiswa dengan dosen dalam interaksi akademik. Tindak asertif mahasiswa yang berorientasi pada fungsi ini lazimnya terjadi ketika dosen mengajukan pernyataan keberatan atau meragukan pendapat mahasiswa, baik yang tertera di dalam naskah skpripsi maupun melalui pernyataan lisan mahasiswa ketika berinteraksi dengan dosen.

\section{Mengemukakan Alasan}

Salah satu tindak asertif yang lazim terungkap dalam interaksi akademik adalah tindak mengemukakan alasan. Penutur menyatakan sesuatu untuk memengaruhi mitra tutur membe- narkan pernyataannya. Dalam konteks ini, tindak mengemukakan alasan dikemukakan oleh mahasiswa untuk mendukung pernyataannya agar dapat dibenarkan atau disepakati oleh dosen sebagai mitra tuturnya. Dalam interaksi akademik, tindak mengemukakan alasan adakalanya digunakan oleh mahasiswa berkaitan dengan latar belakang penelitiannya atau pemilihan variabel penelitiannya.

\section{Menyatakan Penolakan}

Salah satu konsekuensi dari interaksi sosial adalah terjadinya perbedaan pandangan yang berpotensi menimbulkan konflik dan konfrontasi antara penutur dengan mitra tutur. Hal tersebut dapat terjadi dalam menuturkan tindak asertif yang mengemban fungsi menyatakan penolakan. Dalam tindak penolakan ini, penutur menyatakan penolakan terhadap pendapat mitra tutur yang bertentangan dengan pendapat penutur. Jika dikaitkan dengan fungsi sosialnya, tindak menyatakan penolakan cenderung bersifat kompetitif, yakni daya ilokusinya bersaing dengan tujuan sosial.

Kesantunan berbahasa dalam tindak penolakan memegang peranan penting dalam menjamin berlangsungnya komunikasi untuk mencapai kesepahaman dan tujuan bersama. Hal ini didasarkan pada asumsi bahwa kesantunan sebagai sistem hubungan interpersonal dirancang untuk memperkecil potensi bagi terjadinya konflik dan konfrontasi yang selalu ada dalam semua pergaulan manusia.

Tindak asertif yang berfungsi menyatakan penolakan mahasiswa terhadap pendapat dosen potensial terjadi dalam interaksi akademik. Tuturan penolakan yang dikemukakan mahasiswa dalam interaksi akademik dilakukan secara langsung maupun secara tidak langsung pada kegiatan akademik.

\section{Menjawab Pertanyaan}

Tindak asertif yang berfungsi menjawab pertanyaan merupakan salah satu jenis tindak asertif yang pasti ada dalam interaksi akademik, baik dalam seminar proposal, seminar, hasil penelitian, maupun dalam ujian skripsi. Tuturan demikian lazim ditemukan dalam sesi tanya jawab. Secara garis besarnya, ada dua pemarkah kesantunan dalam tindak menjawab pertanyaan, 
yakni relevansi dan 'cara penyampaian'. Relevansi berkaitan dengan isi tuturan, yakni sejauh mana kesesuaian antara jawaban yang dikemukakan mahasiswa dengan pertanyaan yang diajukan dosen. Cara penyampaian berkaitan secara teknis dengan kesantunan bertutur, misalnya: menghormati, menjaga muka, dan se-bagainya.

\section{Memberi Penjelasan}

Tindak asertif memberi penjelasan merupakan salah satu wujud tindak tutur yang lazim ditemukan dalam interaksi akademik. Tindak semacam ini biasanya dituturkan mahasiswa ketika memberi penjelasan sesuai dengan pertanyaan dosen baik dalam ujian skripsi, seminar hasil penelitian maupun dalam seminar proposal mahasiswa. Sesuai dengan fungsinya, pertanyaan dosen dalam interaksi akademik merupakan ujian bagi mahasiswa. Oleh karena itu, penjelasan yang diberikan oleh mahasiswa bukan ditujukan untuk menggurui mitra tuturnya, melainkan untuk dinilai kebenaran proposisinya serta kesantunan penyampaiannya. Penggunaan tindak asertif yang berfungsi memberi penjelasan adakalanya dituturkan mahasiswa ketika dosen meminta penjelasan kepada mahasiswa tentang cara pengambilan sampel.

\section{Menunjukkan}

Menunjukkan merupakan salah satu realisasi kesantunan berbahasa dalam tindak asertif. Dalam tindak asertif yang berfungsi menunjukkan ini, penutur berusaha menyatakan kebenaran suatu pernyataan dan meyakinkan mitra tuturnya dengan cara menunjukkan sesuatu sebagaimana yang dikehendaki mitra tutur. Jika dikaitkan dengan tujuan sosial, daya ilokusi tindak menunjukkan cenderung sejalan dengan tujuan sosial. Namun, dalam penyampaiannya tindak ini tidak terlepas dari kesantunan berbahasa. Ada kalanya penutur mengabaikan kesantunan berbahasa, namun ada kalanya sangat meperhatikan kesantunan berbahasa.

\section{Memberikan Klarifikasi}

Salah satu tindak asertif yang juga lazim terungkap melalui interaksi mahasiswa dengan dosen dalam interaksi akademik adalah tindak asertif yang berfungsi memberikan klarifikasi.
Hal ini didasari oleh fakta bahwa tidak semua pernyataan dapat langsung diterima oleh mitra tutur. Dalam konteks demikian, mitra tutur biasanya meminta klarifikasi atas pernyataan yang disampaikan oleh seorang penutur. Untuk memberikan respon mitra tutur dan memenuhi tuntutan komunikasi, seorang penutur berkewajiban memberikan klarifikasi atas pernyataan yang telah disampaikan sesuai dengan tuntutan mitra tutur. Dalam menyampaikan klarifikasinya, tuturan mahasiswa terkait dengan kesantunan berbahasa.

\section{Menyampaikan Laporan}

Sesuai dengan tujuan pembicaraan dalam interaksi akademik, tindak asertif yang mengemban sebagai penyampaian laporan sangat potensial digunakan dalam interaksi akademik, baik melalui ujian skripsi maupun seminar hasil penelitian. Penyampaian laporan merupakan tindak asertif yang digunakan penutur untuk menyampaikan informasi berupa laporan. Sesuai dengan tindak asertif, penyampaian laporan bertujuan untuk: (1) dinilai benar atau salahnya oleh mitra tutur; dan (2) diterima atau ditolak oleh mitra tutur. Dengan kedua tujuan tersebut, tindak asertif yang mengemban fungsi menyampaikan laporan tersebut akan terkait dengan kesantunan berbahasa.

Penggunaan tindak asertif dengan fungsi menyampaikan laporan adakalanya dituturkan mahasiswa dalam interaksi akademik ketika dosen meminta mahasiswa melaporkan kegiatannya tentang cara mengumpulkan data dalam penelitian dan metode yang digunakan dalam menganalisis data.

\section{Kesantunan dalam Tindak Direktif}

Tindak direktif digunakan untuk menyatakan permintaan agar mitra tutur melakukan atau tidak melakukan sesuatu, misalnya meminta, memerintah, memohon, menuntut, melarang, dan sebagainya. Daya ilokusi tindak tutur ini menghendaki agar mitra tutur melakukan atau tidak melakukan sesuatu sesuai dengan maksud tuturan penutur. Daya ilokusi tindak direktif demikian itu cenderung bersifat kompetitif, yakni tujuan ilokusinya bersaing dengan tujuan sosial. Tindak direktif ini sangat potensial merepresentasikan kesantunan berbahasa. 
Berdasarkan hasil penelitian terungkap bahwa kesantunan dalam tindak direktif sangat beragam. Keragaman tindak direktif ini menyangkut jenis fungsi direktif yang digunakan dan fungsi kesantunan yang direpresentasikan. Jika ditinjau dari jenis fungsi direktif yang digunakan, fungsi kesantunan dalam interaksi akademik tampak direpresentasikan dalam berbagai jenis tindak direktif, yaitu: meminta, memohon, bertanya, menyerahkan, dan menawarkan. Sementara jika ditinjau dari segi fungsi kesantunan yang diembannya, jenis tindak direktif ini memunyai kadar kesantunan yang beragam yang mengarah pada fungsi penghormatan, solidaritas, dan persuasif.

\section{Permintaan}

Permintaan merupakan salah satu jenis tindak direktif yang meminta mitra tutur untuk melakukan sesuatu sesuai dengan maksud penutur. Dalam tindak meminta, penutur menyatakan permintaan kepada mitra tutur dan mitra tutur melakukan sesuatu karena keinginan penutur. Ada sejumlah prasyarat yang mesti dipenuhi untuk mewujudkan tindak meminta, yakni (1) bahwa seseorang yang membuat permintaan Kenyataannya benar-benar menginginkan tindakan yang diinginkannya terlaksana; (2) bahwa seseorang yang padanya permintaan diajukan mampu melaksanakan tindakan yang diminta; (3) bahwa orang yang meminta akan menunjukkan tindakan yang dapat dilakukan oleh orang yang diminta; dan (4) tuturan permintaan dalam bentuk apa pun menggambarkan upaya penutur agar mitra tutur melakukan tindakan yang diinginkan.

Jika dikaitkan dengan daya ilokusinya, suatu permintaan dapat berupa permintaan halus atau tidak selalu tegas sebagai perintah. Oleh karena itu, permintaan lazim digunakan oleh penutur yang memiliki status yang lebih rendah kepada yang lebih tinggi. Namun, dapat pula digunakan oleh penutur yang status sosialnya lebih tinggi kepada yang lebih rendah. Dengan kata lain, tuturan permintaan sangat potensial digunakan oleh mahasiswa ketika berinteraksi dengan dosen dalam interaksi akademik. Bahkan, fungsi meminta inilah yang paling banyak digunakan mahasiswa dibandingkan dengan fungsi direktif yang lain. Permintaan yang digunakan mahasiswa dalam interaksi akademik sangat beragam sesuai dengan spesifikasi permintaan yang dikehendaki mahasiswa. Fungsi permintaan antara lain, meliputi: meminta persetujuan, meminta penegasan, meminta konfirmasi, dan meminta klarifikasi.

\section{Permohonan}

Dengan taraf kesantunan yang lebih tinggi, selain fungsi meminta mahasiswa juga menggunakan tindak direktif dengan fungsi memohon ketika berinteraksi dengan dosen dalam interaksi akademik, baik melalui seminar hasil penelitian maupun dalam ujian skripsi. Pada dasarnya, memohon juga merupakan permintaan, hanya taraf kesantunannya lebih halus. Dalam tindak memohon ini penutur memohon agar mitra tutur melakukan sesuatu sesuai dengan yang dikehandaki oleh penutur. Dengan kata lain, daya ilokusi dari suatu permohonan menghendaki agar mitra tutur berkenan melakukan sesuatu sesuai dengan keinginan penutur.

Hubungan mahasiswa dengan dosen yang bersifat asimetris dalam konteks interaksi akademik, menjadikan situasi tutur demikian sangat potensial memunculkan tuturan mahasiswa dengan fungsi permohonan. Dalam konteks ini, penggunaan tindak direktif dengan fungsi permohonan oleh mahasiswa berkaitan dengan keterbatasan mahasiswa dalam mempertanggungjawabkan skripsinya dalam ujian skripsi. Ketika mahasiswa tidak mampu menjawab pertanyaan dosen yang berkaitan dengan tulisannya dalam skripsi, mahasiswa memohon kepada dosen agar memberikan informasi tambahan untuk melengkapi skripsinya.

\section{Pertanyaan}

Pertanyaan merupakan salah satu fungsi direktif yang menghendaki adanya respon dari mitra tutur. Respon yang diharapkan dapat bervariasi sesuai dengan jenis pertanyaan yang disampaikan. Berdasarkan tujuan pertanyaan tersebut, respon yang diharapan dapat berupa: jawaban ya/ tidak, menghendaki informasi, atau menghendaki jawaban berupa perbuatan. Tindak direktif yang mengemban fungsi pertanyaan antara lain ditandai pemarkah pertanyaan berupa kata tanya dan intonasi bertanya.

Berdasarkan temuan penelitian, penggunaan tindak direktif yang mengemban fungsi pertanyaan digunakan secara bervariasi oleh maha- 
siswa ketika berinterakasi dengan dosen dalam interaksi akademik. Pertanyaan yang disampaikan mahasiswa dengan menggunakan kata tanya.

\section{Kesantunan dalam Tindak Komisif}

Tindak komisif digunakan untuk menyatakan sesuatu yang menunjukkan bahwa penutur sedikit banyak terikat pada suatu tindakan di masa depan, misalnya menjanjikan atau menawarkan. Daya ilokusi tindak tutur ini menghendaki agar mitra tutur mempercayai sesuatu yang dijanjikan atau ditawarkan oleh penutur sesuai dengan maksud tuturan penutur. Karena orientasinya yang lebih cenderung kepada mitra tutur, daya ilokusi tindak komisif demikian itu cenderung bersifat menyenangkan dan kurang bersifat kompetitif, yakni tujuan ilokusinya sejalan dengan tujuan sosial. Oleh karena itu, dalam realisasinya, tidak komisif ini sangat potensial merepresentasikan kesantunan berbahasa.

Berdasarkan hasil penelitian terungkap bahwa representasi kesantunan dalam tindak komisif beragam. Keragaman komisif menyangkut jenis komisif yang digunakan dan fungsi kesantunan yang direpresentasikan. Jika ditinjau dari jenis komisif yang digunakan, kesantunan dalam interaksi akademik direpresentasikan dalam berbagai jenis tindak komisif, yaitu: menyatakan kesediaan, menyatakan persetujuan, menyatakan janji, menyatakan kesediaan, dan menyatakan keyakinan. Sementara jika ditinjau dari segi fungsi kesantunan yang diembannya, jenis tindak komisif ini memunyai kadar kesantunan yang mengarah pada fungsi penghormatan, solidaritas, dan persuasif.

\section{Menyatakan Kesiapan}

Tindak menyatakan kesiapan merupakan salah satu jenis tindak komisif yang menunjukkan bahwa penutur siap melakukan sesuatu di masa depan sesuai dengan maksud tuturan. Dalam tindak menyatakan kesiapan, penutur menyatakan kesiapannya kepada mitra tutur untuk melakukan sesuatu sesuai keinginan mitra tutur.

Dalam interaksi akademik, tindak komisif yang mengemban fungsi menyatakan kesiapan dapat dituturkan oleh mahasiswa ketika dosen mengajukan pernyataan yang meminta kesiapan dari mahasiswa. Tuturan demikian antara lain diwujudkan ketika dosen meminta kesiapan mahasiswa untuk mengikuti ujian.

\section{Menyatakan Kesediaan}

Daya ilokusi tindak komisif yang menyatakan kesediaan memiliki kemiripan dengan fungsi menyatakan kesiapan. Dalam tindak menyatakan kesediaan ini penutur menyatakan kesediaannya untuk mengikuti apa yang dikehendaki mitra tuturnya dalam tuturannya. Dalam interaksi akademik, tindak menyatakan kesediaan yang dinyatakan oleh mahasiswa kepada dosen pada umumnya berkenaan dengan kesediaan mahasiswa mengikuti perintah, saran, atau tuntutan dosen kepada mahasiswa.

\section{Menyatakan Persetujuan}

Dalam tindak komisif yang menyatakan persetujuan, penutur menyampaikan tuturannya sesuai dengan tuturan yang disampaikan oleh mitra tuturnya. Tindak komisif yang menyatakan persetujuan dapat ditandai dengan dua ciri utama, yakni dengan cara pengungkan dan respon mengiyakan. Tindak menyatakan persetujuan yang dituturkan mahasiswa ketika berinteraksi dengan dosen dalam interaksi akademik paling sering melalui penggunaan respon mengiyakan.

\section{Menyatakan Janji}

Tindak komisif yang direpresentasikan mahasiswa dalam interaksi akademik juga ditemukan dalam menyatakan janji. Dalam tindak menyatakan janji ini, penutur menyatakan sesuatu yang menunjukkan bahwa penutur sedikit atau banyak terikat pada suatu tindakan di masa depan. Sesuai dengan peran mahasiswa dalam peristiwa tutur ketika berinteraksi dengan dosen, tindak menyatakan janji sering kali digunakan mahasiswa melalui pemberian respon mengiyakan atas permintaan dosen. Respon tersebut merupakan bentuk kesantunan terhadap dosen yang memiliki strata sosial lebih tinggi.

\section{Kesantunan dalam Tindak Ekspresif}

Tindak ekspresif digunakan untuk mengungkapkan atau mengutarakan sikap psikologis penutur terhadap keadaan yang tersirat dalam i- 
lokusi, misalnya mengucapkan terima kasih, memberi maaf, mengecam, memuji, mengucapkan belasungkawa, dan sebagainya. Daya ilokusi tindak tutur ini menghendaki agar mitra tutur merasakan sesuatu sebagaimana yang dirasakan oleh penutur sesuai dengan maksud tuturan penutur. Daya ilokusi tindak ekspresif dapat bernilai positif (rasa senang) dan dapat pula bernilai negatif (rasa tidak senang). Oleh karena itu, tindak ekspresif ini dapat bersifat konvival dan dapat pula bersifat kompetitif, yakni tujuan ilokusinya kadang sejalan dengan tujuan sosial, dan kadang pula bersaing dengan tujuan sosial. Dalam realisasinya, tindak komisif ini sangat potensial merepresentasikan kesantunan berbahasa.

Berdasarkan hasil penelitian terungkap bahwa representasi kesantunan dalam tindak ekspresif beragam. Keragaman fungsi ekspresif ini menyangkut jenis fungsi ekspresif yang digunakan dan fungsi kesantunan yang direpresentasikan. Jika ditinjau dari jenis fungsi ekspresif yang digunakan, kesantunan dalam interaksi akademik tampak direpresentasikan dalam berbagai jenis tindak komisif, antara lain: mengungkapkan permohonan maaf, mengungkapkan terima kasih, mengakui kesalahan, mengungkapkan kepuasan, mengungkapkan keluhan, mengungkapkan permohonan maaf, menyatakan kesepakatan, dan mengakui kekurangan. Jika ditinjau dari segi fungsi kesantunan yang diembannya, jenis tindak ekspresif ini memunyai kadar kesantunan yang beragam yang mengarah pada fungsi penghormatan, solidaritas, maupun persuasif.

\section{Permohonan Maaf}

Salah satu representasi kesantunan dalam tindak ekspresif adalah fungsi permohonan maaf. Dalam tindak permohonan maaf, penutur mengekspresikan perasaan dan sikap bersalahnya secara psikologis kepada mitra tutur mengenai suatu peristiwa atau keadaan. Tindak ekspresif dalam interaksi akademik yang menyatakan permohonan maaf antara lain dituturkan ketika mahasiswa merasa bersalah dalam mempertahankan pendapatnya dan membantah pendapat dosen, namun ternyata pendapat tersebut keliru.

\section{Mengungkapkan Terima Kasih}

Ungkapan terima kasih merupakan salah satu tindak ekspresif yang sering ditemukan da- lam interaksi sosial. Hal ini didasarkan pada karakter dasar interaksi sosial yang saling memberi dan menerima informasi. Dalam interaksi akademik, tindak ekspresif yang menyatakan fungsi mengungkapkan terima kasih antara lain diungkapkan mahasiswa ketika dosen memberkan kebijakan yang menguntungkan mahasiswa.

\section{Mengungkapkan Kepuasan}

Tindak ekspresif yang digunakan dalam interaksi mahasiswa dengan dosen dalam interaksi akademik lazim pula digunakan untuk mengungkapkan rasa kepuasan. Ungkapan kepuasan yang diekspresikan mahasiswa dalam interaksi akademik terkait dengan kesuksesan mahasiswa menjalani ujian maupun seminar hasil penelitian dan dinyatakan lulus. Dalam konteks demikian, tuturan ekepresif biasanya merupakan respon ekspresif dari tindak deklarasi yang disampaikan oleh dosen. Melalui tindak deklarasi dosen mengubah dunia mahasiswa. Dalam ujian skripsi, dosen melalui tindak deklarasi mengubah status mahasiswa dari mahasiswa menjadi sarjana. Perubahan status yang demikian berarti itulah yang lazim memunculkan tindak ekspresif dari mahasiswa yang mengemban fungsi mengungkapkan kepuasan, rasa senang, bangga, dan terharu terhadap apa yang sedang dialaminya.

\section{Mengakui Kesalahan}

Tindak ekspresif dalam interaksi mahasiswa dengan dosen dalam interaksi akademik digunakan ketika mengungkapkan rasa bersalah. Ungkapan rasa bersalah diekspresikan mahasiswa dalam interaksi akademik ketika mahasiswa terlanjur melakukan kesalahan.

\section{Mengungkapkan Perhatian}

Tindak ekspresif dalam interaksi mahasiswa dengan dosen dalam interaksi akademik juga digunakan untuk mengungkapkan perhatian. Dalam konteks ini, penutur menggunakan tuturan untuk menunjukkan perhatian atas tuturan mitra tutur. Dalam interaksi akademik, tindak ekspresif mahasiswa yang berfungsi untuk mengungkapkan perhatian biasanya digunakan mahasiswa untuk memberikan respon atas tuturan dosen yang meminta perhatian mahasiswa. Hal ini an- 
tara lain ditandai oleh teguran dosen dengan menyebutkan nama mahasiswa dalam tuturan dosen.

\section{PEMBAHASAN}

Kesantunan berbahasa dalam perspektif etnografi komunikasi secara lebih spesifik terkait dengan tiga unit dasar komunikasi sebagaimana yang diidentifikasi Hymes (1972), yakni: situasi komunikatif, peristiwa komunikatif, dan tindak komunikatif. Situasi komunikatif merupakan konteks terjadinya komunikasi, dalam konteks ini adalah kampus. Namun, situasi komunikatif tersebut berubah-ubah sesuai dengan aktivitas yang terjadi di dalamnya. Oleh karena itu, kampus sebagai situasi komunikatif yang merepresentasikan kesantunan berbahasa hanya akan representatif jika dimanfaatkan untuk komunikasi akademik. Peristiwa komunikasi merupakan unit komunikasi untuk tujuan deskriptif. Sebuah peristiwa tertentu didefinisikan sebagai keseluruhan perangkat komponen yang utuh yang diawali dengan tujuan umum komunikasi, topik umum yang sama, yang secara umum menggunakan variasi bahasa yang sama, mempertahankan nada dan kaidah yang sama untuk berinteraksi, dalam setting yang sama. Tindak komunikatif pada umumnya terfokus dengan fungsi interaksi tunggal, seperti pernyataan, referensial, permohonan, atau perintah.

Kesantunan berbahasa dalam interaksi akademik diwujudkan melalui tindak tutur sebagai unit dasar komunikasi. Namun, dalam perspektif etnografi komunikasi kajian tindak tutur ini diperluas untuk mencakup rentang fenomena yang lebih luas dalam etnografi komunikasi, dan memungkinkan adanya perbedaan dalam segmen-segmen bahasa yang dipandang sebagai unit fungsional dasar oleh anggota-anggota masyarakat tutur yang berbeda.

Sebagai kajian kesantunan, kesantunan berbahasa memiliki relevansi melalui berbagai teori kesantunan berbahasa. Kesantunan berbahasa dalam kerangka teori kesantunan Robin Lakoff diarahkan pada dua aspek utama. Pertama, kesantunan berbahasa mahasiswa dalam kaitannya dengan definisi kesantunan. Lakoff (1990: 34) mendefinisikan kesantunan sebagai sistem hubungan interpresonal yang dirancang untuk mempermudah interaksi dengan memper-kecil potensi bagi terjadinya konflik dan kon-frontasi yang selalu ada dalam semua pergaulan manusia. Sejalan dengan batasan kesantunan Lakoff tersebut kesantunan berbahasa dalam interaksi akademik sebagai sistem hubungan interpersonal antara mahasiswa dengan dosen dirancang sedemikian rupa untuk menjalankan fungsinya guna mempermudah interaksi serta berusaha memperkecil potensi terjadinya konflik dan konfrontasi antara mahasiswa dengan dosen dalam interaksi akademik. Kedua, kesantunan berbahasa mahasiswa dalam interaksi akademik memiliki relevansi melalui tiga maksim utama kesantunan Lakoff, yakni: (1) jangan mengganggu; (2) berilah opsi; dan (3) buatlah mitra tutur merasa senang, bersikaplah ramah. Ketiga maksim inilah yang seringkali didayagunakan mahasiswa untuk merepresentasikan kesantunan berbahasa ketika berinterkasi dengan dosen dalam interaksi akademik. Semakin taat mahasiswa menerapkan ketiga maksim tersebut, semakin santun tuturan yang dihasilkan. Sebaliknya, semakin tinggi frekuensi pelanggaran mahasiswa terhadap ketiga maksim tersebut, semakin kurang santun tuturan yang dihasilkan.

Pada prinsipnya, representasi kesantunan berbahasa mahasiswa dalam interaksi akademik mengemban fungsi untuk menciptakan suasana sebagaimana yang diajukan oleh Lakoff melalui ketiga maksim tersebut. Maksim ini terejawantahkan dalam tuturan mahasiswa yang senantiasa berusaha untuk memberikan kesempatan kepada mitra tutur untuk menyampaikan tuturannya secara sempurna sebelum memberikan respon atau jawaban atas tuturan atau pertanyaan dosen sebagai mitra tuturnya. Hal ini antara lain dapat terlihat ketika mahasiswa menyampaikan pendapat, mempertahankan pendapat, menjawab pertanyaan, maupun ketika mengemukakan alasan. Demikian halnya dengan maksim yang kedua, dalam interaksi mahasiswa dengan dosen dalam interaksi akademik, mahasiswa senantiasa berusaha untuk tidak memaksa mitra tutur dengan memberikan opsi kepada dosen untuk memberikan keputusan akhir berdasarkan power keilmuan yang mereka miliki. Adapun, pengejawantahan maksim ketiga, yakni anjuran untuk membuat mitra tutur merasa aman dan nyaman ditempuh antara lain melalui sikap santun mahasiswa untuk tetap menjaga muka mitra tutur sehingga terhindar dari berbagai ancaman muka yang memang senantiasa potensial dalam interaksi akademik. 
Dalam perspektif kesantunan Brown dan Levinson (Brown dan Levinson, 1990), kesantunan berbahasa mahasiswa dalam interaksi akademik relevan kaitannya dengan dua tema sentral kajian kesantunan Brown dan Levinson yakni: rasionalitas dan muka. Kedua tema tersebut dinyatakan sebagai ciri-ciri universal yang dimiliki oleh semua penutur dan mitra tutur.

Berdasarkan konsep rasionalitas, fungsi kesantunan berbahasa dalam interaksi akademik didasarkan pada penalaran atau logika saranatujuan. Berdasarkan konsep muka, kesantunan berbahasa dengan berbagai variasinya senantiasa mempertimbangkan muka mitra tutur, baik muka positif maupun muka negatif mitra tutur. Untuk menjaga muka positif mitra tutur, mahasiswa senantiasa berusaha untuk memenuhi keinginan dosen sebagai mitra tutur.

Pada sisi lain, untuk menjaga muka negatif mitra tutur, mahasiswa senantiasa berusaha untuk tidak menghalangi setiap tindak tutur yang disampaikan oleh dosen sebagai mitra tuturnya. Hal ini didasarkan pada pandangan bahwa sebagian besar tindak tutur selalu mengancam keinginan muka para penutur maupun mitra tutur, dan kesantunan berfungsi untuk memperbaiki ancaman muka tersebut.

Untuk menjaga muka mitra tutur, mahasiswa menempuh berbagai strategi, yang oleh Brown dan Levinson diidentifikasi menjadi tiga strategi utama, yakni kesantunan positif, kesantunan negatif, dan kesantunan off-record. Kesantunan positif yang direpresentasikan mahasiswa dimaksudkan sebagai solidaritas yang direalisasikan dengan cara memperhatikan muka positif mitra tutur. Strategi ini bertujuan menjaga perasaan dari mitra tutur. Kesantunan negatif direpresentasikan sebagai ekspresi pemaksaan yang direalisasikan dengan berusaha memperhatikan keinginan muka negatif mitra tutur. Kesantunan off-record direalisasikan melalui penghindaran pemaksaan tertentu dengan memberikan isyarat sebagai pengganti persetujuan permohonan langsung. Mahasiswa tidak menggunakan tuturan, tetapi memanfaatkan berbagai aspek nonlinguistik yang menunjukkan perilaku kesantunan terhadap mitra tutur.

Kesantunan berbahasa mahasiswa dalam interaksi akademik juga relevan melalui teori kesantunan Leech. Dalam perspektif kesantunan Leech (Leech, 1993), kesantunan berbahasa mahasiswa dalam interaksi akademik ditempatkan dalam kerangka 'retorika interpersonal'. Dalam kerangka tersebut, kesantunan berbahasa mahasiswa dalam interaksi akademik dibedakan secara luas antara semantik dengan pragmatik. Semantik sebagai bidang tata bahasa yang berupa sistem kode linguistik berurusan dengan makna atau rasa logika yang abstrak sebuah kalimat. Pragmatik sebagai bidang retorika yang mengimplementasikan kode berkaitan hubungan antara rasa sebuah kalimat dan daya pragmatisnya, yakni makna komunikatifnya. Dari kedua bidang tersebut, representasi fungsi kesantunan berbahasa lebih berkaitan dengan bidang pragmatik. Kesantunan berbahasa mahasiswa dalam interaksi akademik sebagai fenomena pragmatik diatur oleh prinsip yang bersifat normatif, relatif dalam penerapannya, dapat bertentangan dengan prinsip-prinsip yang ada bersama-sama dan mengacu pada nilai-nilai yang bersifat terus-menerus dan bukannya nilai yang bersifat sendiri-sendiri.

Secara lebih khusus, kesantunan berbahasa mahasiswa dalam interaksi akademik senantiasa menerapkan prinsip-prinsip kesantunan Leech (1993). Kesantunan berbahasa mahasiswa dalam menyampaikan berbagai fungsi tuturan senantiasa menerapkan prinsip kesantunan Leech. Untuk menunjukkan penghormatan kepada mitra tutur, penutur senantiasa berusaha menerapkan: (1) maksim kebijaksanaan dengan berusaha mengurangi kerugian mitra tutur serta menambah keuntungan mitra tutur; (2) maksim kedermawanan dengan cara senantiasa berusaha mengurangi keuntungan dan menambah kerugian pada diri sendiri; (3) maksim penghargaan dengan cara senantiasa berusaha mengurangi cacian dan menambah pujian pada mitra tuturnya; maksim kesederhanaan difungsikan dengan cara senantiasa mengurangi pujian dan menambah cacian pada diri sendiri; (4) maksim permufakatan dengan cara senantiasa berusaha mengurangi ketidaksesuaian serta berusaha meningkatkan persesuaian antara diri dengan orang lain; (5) maksim simpati dengan cara senantiasa berusaha mengurangi antipati serta memperbesar simpati antara diri sendiri dengan orang lain.

Dalam perspektif kesantunan budaya, kesantunan berbahasa mahasiswa dalam interaksi akademik juga mendapatkan pembenaran teoretis dalam kerangka teori kesantunan yang dikemukakan oleh Blum-Kulka. Blum-Kulka (dalam Eelen, 2007) memandang bahwa kesantunan sebagai sebuah perilaku sosial yang sesuai dengan harapan-harapan kultural atau norma-norma kultural. Secara teoretis, ia berpendapat bahwa sis- 
tem-sistem kesantunan mewujud-kan interpretasi yang tersaring secara kultural terhadap interaksi antara empat parameter yang sangat penting, yakni: motivasi sosial, mode ekspresi, diferensiasi sosial, dan makna sosial.

Dalam kaitannya dengan representasi fungsi kesantunan berbahasa dalam interaksi akademik, motivasi sosial mengacu pada alasan mengapa mahasiswa bersikap santun, yakni mengacu pada fungsionalitas kesantunan. Mode ekspresi mengacu pada bentuk-bentuk linguistik yang berbeda dan digunakan mahasiswa dalam interaksi akademik untuk menunjukkan kesantunan. Diferensiasi sosial mengacu pada parameter-parameter penilaian sosial yang senantiasa dipertimbangkan mahasiswa karena hal tersebut memainkan peran dalam kesantunan. Makna sosial mengacu pada nilai kesantunan ekspresiekspresi linguistik tertentu dalam berbagai konteks situasi tertentu.

Dari keempat parameter tersebut, motivasi sosial merupakan parameter yang memiliki relevansi yang sangat signifikan dengan kesantunan berbahasa mahasiswa dalam interaksi akademik. Hasil penelitian ini menunjukkan bahwa motivasi sosial kesantunan berbahasa mahasiswa dalam interaksi akademik antara lain, meliputi fungsi penghormatan, fungsi solidaritas, fungsi persuasif, fungsi penambah keakraban, fungsi menyelamatkan muka, dan fungsi menyenangkan mitra tutur. Motivasi sosial itulah yang selanjutnya direpresentasikan melalui mode ekspresi dan didayagunakan mahasiswa untuk merepresentasikan keragaman kesantunan melalui tindak asertif, direktif, komisif, dan ekspresif.

Kesantunan berbahasa mahasiswa dengan berbagai variasinya dalam interaksi akademik, dalam konteks sosiokultural yang lebih luas tidak mungkin dilepaskan dari kajian sosiolinguistik, baik secara mikro mapun makro. Sosiolinguistik menempatkan kedudukan bahasa dalam hubungannya dengan pemakaiannya di dalam masyarakat. Ini berarti bahwa sosiolinguistik memandang bahasa pertama-tama sebagai sistem sosial dan sistem komunikasi, serta merupakan bagian dari masyarakat dan kebudayaan tertentu. Dalam konteks sosiolinguistik mikro, keragaman fungsi kesantunan berbahasa dipandang sebagai representasi dari interaksi bahasa antarpenutur di dalam suatu kelompok masyarakat tutur dengan tindak tutur sebagai pusat perhatiannya.
Sebaliknya, dalam sosiolinguistik makro fenomena tersebut dipandang sebagai representasi interaksi bahasa antarpenutur dalam konteks antarkelompok dan berusaha melihat distribusi perbedaan-perbedaan wujud tersebut menurut umur, jenis kelamin, pekerjaan, etnis, dan berbagai variabel sosiokultural lainnya. Variabelvariabel tersebut dapat menunjukkan pengunaan bahasa yang berbeda.

Uraian tersebut menunjukkan perbedaan antara pendekatan sosilinguistik makro dan sosiolinguistik mikro. Melalui pendekatan sosiolinguistik mikro, kesantunan berbahasa dengan berbagai variasinya didekati sebagai fenomena linguistik. Sebaliknya, melalui pendekatan sosiolinguistik makro, kesantunan berbahasa dengan berbagai variasinya itu lebih cenderung didekati sebagai fenomena sosial.

\section{SIMPULAN}

Berdasarkan temuan penelitian dan pembahasan yang telah dipaparkan, dapat disimpulkan bahwa kesantunan berbahasa mahasiswa dalam interaksi akademik disampaikan melalui empat jenis tindak tutur, yakni: (1) kesantunan dalam tindak asertif; (2) kesantunan dalam tindak direktif; (3) kesantunan dalam tindak komisif; dan (4) kesantunan dalam tindak ekspresif.

Kesantunan dalam tindak asertif, meliputi: (a) mengemukakan pendapat; (b) mempertahankan pendapat; (c) mengemukakan alasan; (d) menyatakan penolakan; (e) menjawab pertanyaan; (f) menunjukkan; (g) memberikan klarifikasi; dan (h) menyampaikan laporan.

Kesantunan dalam tindak direktif meliputi: (a) permintaan; (b) permohonan; dan (c) pertanyaan. Kesantunan dalam tindak komisif, meliputi: (a) menyatakan kesiapan; (b) menyatakan kesediaan; (c) menyatakan persetujuan; dan (d) menyatakan janji. Kesantunan dalam tindak ekspresif meliputi: (a) permohonan maaf; (b) mengungkapkan terima kasih; (c) mengungkapkan kepuasan; (d) mengakui kesalahan; dan (e) mengungkapkan perhatian.

Lebih lanjut, dapat disimpulkan bahwa kesantunan berbahasa mahasiswa dalam interaksi akademik yang direpresentasikan melalui fungsi tindak tutur asertif, direktif, komisif, dan ekspresif dengan beragam fungsi yang diembannya masing-masing memiliki relevansi kesantunan dengan aneka teori kesantunan berbahasa. 



\section{DAFTAR PUSTAKA}

Blum-Kulka, Shoshana. 1992. The Metapragmatics of Politeness in Israel Society, in Richard Watts, S. Ide, K. Ehlich (Eds.). Politeness in Language: Studies in its History, Theory and Practice. Berlin: Mouton de Gruyter.

Brown, G. and Yule, G. 1983. Discourse Analysis. Cambridge: Cambridge University Press.

Bungin, Burhan (Ed.). 2006. Metodologi Penelitian Kualitatif. Jakarta: PT RajaGrafindo Persada.

Cummings, Louise. 2007. Pragmatik: Sebuah Perspektif Multidisipliner. Terjemahan oleh Abdul Syukur Ibrahim (Ed.). Yogyakarta: Pustaka Pelajar.

Eelen, Gino. 2006. Kritik Teori Kesantunan. Terjemahan oleh Abdul Syukur Ibrahim (Peny.). Surabaya: Airlangga University Press.

Gunarwan, A. 1994. Kesantunan Negatif di Kalangan Dwibahasawan Indonesia-Jawa di Jakarta: Kajian Sosiopragmatik. PELLBA 7:81-122. Jakarta: Lembaga Bahasa Unika Atmajaya.

Halliday, M.A.K. 1987. Language Structure and Language Function dalam John Lyons et.al. New Horizonin Linguistics. London: Penguin.

Hymes, Dell. 1974. Foundation in Sociolinguistics: An Etnographic Approach. Philadephia: University of Pennsylvan Press, Inc.
Ibrahim, Abdul Syukur. 1993. Kajian Tindak Tutur. Surabaya: Usaha Nasional.

Ibrahim, Abdul Syukur. 1996. Bentuk Direktif Bahasa Indonesia. Disertasi tidak diterbitkan. Surabaya: PPS Universitas Airlangga.

Leech, Geoffrey. 1983. Prinsip-Prinsip Pragmatik. Terjemahan oleh M.D.D. Oka. 1993. Jakarta: Universitas Indonesia (UI Press).

Mahsun. 2005. Metode Penelitian Bahasa: Tahapan Strategi, Metode, dan Tekniknya. Jakarta: PT RajaGrafindo Persada.

Mey, Jakob L. 1996. Pragmatics: An Introduction. Oxford: Blackwell.

Rahardi, Kunjana. 2005. Pragmatik: Kesantunan Imperatif Bahasa Indonesia. Jakarta: Erlangga.

Richard, Jack C. 1995. Tentang Percakapan. Terjemahan oleh Ismari. Surabaya: Airlangga University Press.

Syahrul R. 2007. Representasi Kesantunan Tindak Tutur Berbahasa Indonesia Guru dalam Pembelajaran di Kelas: Kajian Etnografi Кoтиnikasi di SMA PMT Hamka Padang Pariaman. Disertasi tidak diterbitkan. Malang: PPs. UM Malang.

Yule, George. 2006. Pragmatik. Terjemahan oleh Indah Fajar wahyuni. Yogyakarta: Pustaka Pelajar. 